\title{
Point-Of-Use Drinking Water Treatment in the Developing World: Community Acceptance, Project Monitoring and Revision
}

\author{
Temitope A. Ogunyoku \\ PhD Candidate, Department of Civil and Environmental Engineering \\ University of California - Davis \\ Davis, CA, 95616 \\ Taogunyoku@ucdavis.edu \\ Daniel M. Nover \\ PhD Candidate, Department of Civil and Environmental Engineering \\ University of California - Davis \\ Davis, CA, 95616 \\ dmnover@ucdavis.edu \\ Erica R. McKenzie \\ PhD Candidate, Department of Civil and Environmental Engineering \\ University of California - Davis \\ Davis, CA, 95616 \\ ermckenzie@ucdavis.edu \\ Geetika Joshi \\ PhD Candidate, Department of Land, Air and Water Resources \\ University of California - Davis \\ Davis, CA, 95616 \\ gjoshi@ucdavis.edu \\ William E. Fleenor, PhD \\ Assistant Project Scientist, Department of Civil and Environmental Engineering \\ University of California - Davis \\ Davis, CA, 95616 \\ wefleenor@ucdavis.edu
}

Abstract - Project design and implementation of water treatment technologies in the developing world often overlooks potential pitfalls for many reasons, notably because: 1) technical experts focus on technologies without considering cultural acceptability and 2) projects lack monitoring, evaluation, and revision. Over the past five years, Engineers Without Borders (EWB) at UC-Davis has partnered with the Rural Agency for Sustainable Development (RASD) in Nkokonjeru, Uganda, to implement sustainable point of use (POU) water systems. POU systems (i.e. Filtron clay pot filters, solar disinfection, chlorine treatment, and colloidal silver) were tested and implemented at RASD's training center in Nkokonjeru. While all of the systems effectively removed pathogens, cultural appropriateness and education were the most important drivers of project acceptance. After a one-year assessment, it was determined that community preference was driven by transparency of treatment method, cost, stigma, and ease of use. Clay pot filters were preferred because of ease of use and physical particle removal capabilities. However, high cost, lack of local production and transportation difficulties dictated that their use was not sustainable. Biosand filters were introduced as an alternative and although originally deemed to be too complicated, they have been accepted by the community and continue to be manufactured by RASD in Nkokonjeru. 
Index Terms - Drinking water treatment, international development, participatory assessment, point of use

\section{Introduction}

In 2010, it was estimated that just under 1 billion people lacked access to improved water sources ${ }^{16}$. The need for water in developing countries is a growing concern as domestic and industrial demands quickly outstrip the capacity of developing countries, especially in rural settings, to develop water resources ${ }^{21}$. In many rural communities, water must be hauled over long distances from shared sources ${ }^{20}$.

Numerous health problems are closely tied to issues of water supply and water resources management. Diarrheal disease is the most important water related health problem as it impacts many people each year and is particularly devastating to children. Currently, 1.8 million people, $90 \%$ children, die every year due to diarrheal diseases. Unsafe water supplies and poor sanitation account for $88 \%$ of diarrheal diseases ${ }^{19}$. Other diseases are exacerbated by poor water resources management, most notably mosquito born diseases, like malaria, dengue fever and Japanese encephalitis, all of which are associated with standing water ${ }^{2}$.

Communities that do have some level of improved water supply often evolve over time from extremely low population densities to higher population densities, without parallel improvements in water supply and distribution systems. As a consequence, even systems that were adequate at one time become overwhelmed by densely constructed latrines in close proximity to hand pumps, shallow wells and springs. More sophisticated aquifer withdrawal systems and water treatment technologies are extremely capital intensive, requiring large investments and skilled labor that many developing nations and rural communities lack ${ }^{6}$.

\section{Engineering Solutions and Cultural Context}

Major problems with water treatment system implementation are project cost, availability of relevant skills, and cultural appropriateness. Often, proposed technologies focus on implementing technologies that have been successful in the visiting engineer's home country and community, in a completely different social and economic context ${ }^{15}$. Additionally, water projects tend to be administered in top-down fashion, ignoring the preferences of project users and beneficiaries ${ }^{7}$. As a consequence, consumers fail to adopt the implemented solution because they do not have the finance, knowledge, or political capacity to use and sustain the implemented solution. Worse, implemented solutions are often culturally inappropriate, with implementers failing to consider the context in which they are working. The combined effect of these cultural considerations complicates successful project implementation, even in situations where the technological foundation for the project is sound.

\section{Sustainability, Community Participation, and the Project Cycle}

The recognition that successful projects demand community participation and a clear understanding of the socio-cultural context in which the project is implemented has led to increasing focus on factors that contribute to project sustainability. Identifying and successfully applying appropriate technologies depends on numerous factors, ranging from politics to economic factors like income, material, and labor costs to social factors like stigma, cultural acceptability, and gender roles. Communities in developing countries are unique and project implementation must be conducted on a case-by-case basis.

Recognizing the individuality of different cultures and different communities, participatory approaches to project design and implementation are necessary for project sustainability. In addition to participation from community members, active and engaged 
community partners are necessary to facilitate successful project implementation. Finally, monitoring and evaluation and subsequent project revision are necessary in all engineering projects and this is especially true in the developing world, where small-scale projects must be implemented in numerous households in parallel with education and outreach efforts. This requirement increases the importance of a solid community partner and an understanding of local culture and conditions.

It is the objective of this manuscript to explore 1) the importance of assessment, monitoring and evaluation in project success and 2) the importance of community participation and feed back in project design. In order to achieve these objectives, we present our experience in Nkokonjeru in three parts. The first part was project assessment, in which we surveyed community members in order to identify needs, assets and preferences, and we surveyed infrastructure and water resources to identify prevailing conditions with respect to water quality and water supply. The second part is implementation, in which we tested four water treatment technologies and assessed technical performance, community acceptance, and large-scale implementation feasibility. Finally, we present monitoring and evaluation, in which we identify the performance of the community's preferred treatment technology including pitfalls identified and project revision necessary to achieve long-term project success.

\section{Project Site: Nkokonjeru, Uganda}

Rural Uganda accounts for $87 \%$ of the country's total population of 29.9 million ${ }^{18}$. The rural poor make up more than two-thirds of Uganda's impoverished people ${ }^{12}$ and lack of access to clean water and adequate sanitation are closely tied to poverty ${ }^{11,15}$. Although efforts ranging from microfinance to sanitation interventions have been made to reduce the poverty level in Uganda, they have largely focused on urban areas. In the past decade, urban areas experienced $43 \%$ reduction in poverty while rural areas have only managed an $18 \%$ reduction ${ }^{12}$.

Nkokonjeru is an agricultural community located in the Buikwe district about $30 \mathrm{~km}$ east of the capital city Kampala (Figure 1A and 1B). Nkokonjeru and the immediate surrounding area of 11 villages have approximately 12,000 inhabitants. Nkokonjeru's town center is the business hub of the region with a market place and main street with many small shops. The surrounding villages are more rural and most of the economy is based on subsistence farming. Drinking water quality continues to be an issue that affects the general health and economy of the entire region. Education about water and health is inadequate and those that are educated are often economically unable to alter their situation. 
A)

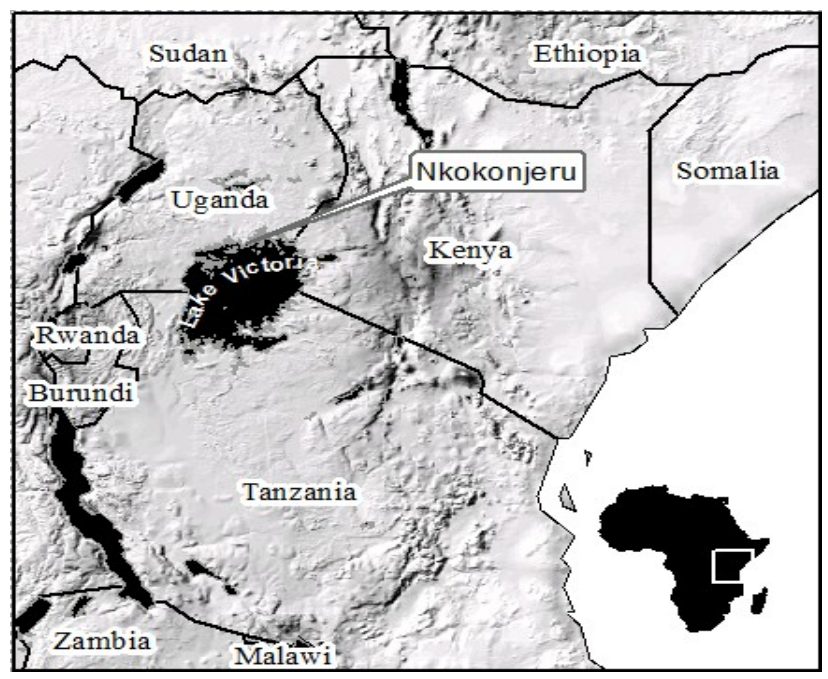

B)

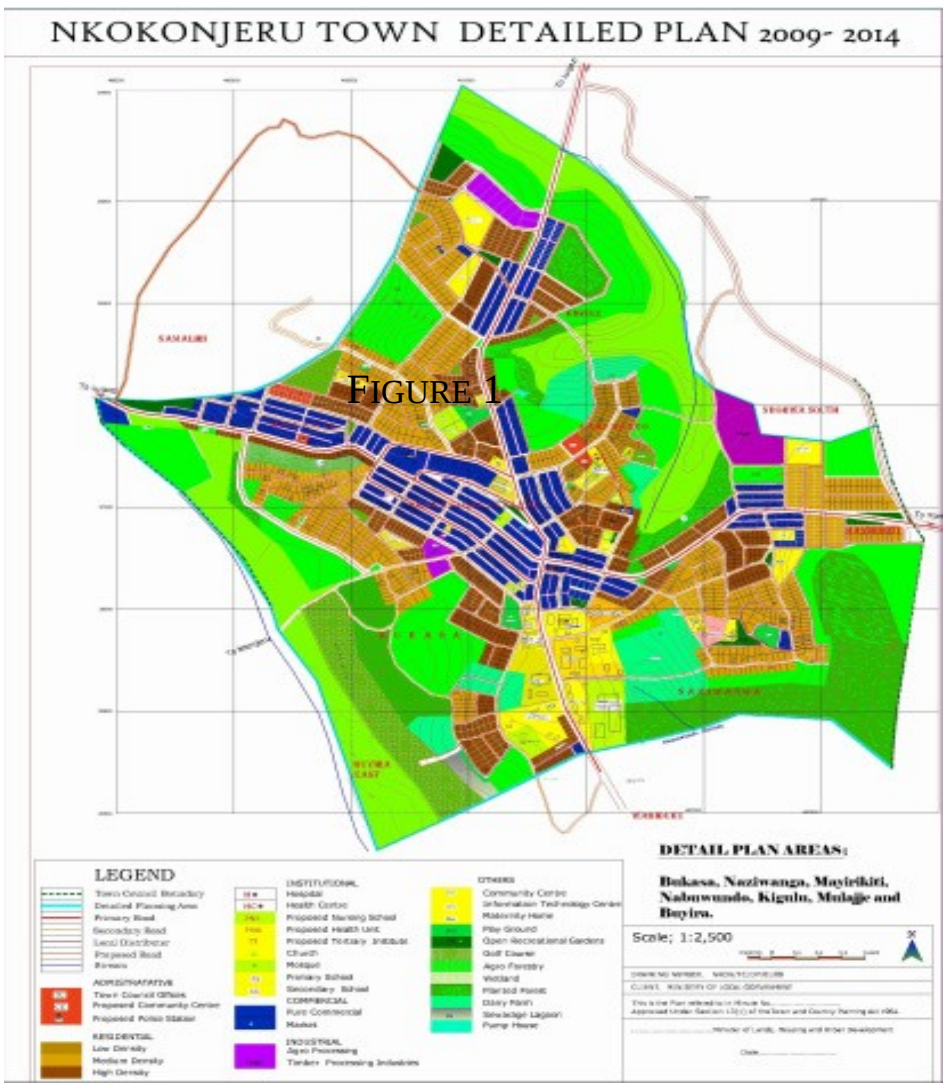

FIGURE 1

A) MAP SHOWING LOCATION OF STUDY AREA IN NKOKONJERU, 30 KM EAST OF KAMPALA, NEAR THE SHORES OF LAKE VICTORIA (COURTESY OF JOSHUA VIERS, WATERSHED SCIENCES, UC DAVIS AND B) DETAIL MAP OF NKOKONJERU AND SURROUNDING AREAS, INCLUDING LAND USE AND 5 YEAR DEVELOPMENT PLAN (COURTESY OF NKOKONJERU TOWN COUNCIL) 
Engineers Without Borders - Davis and The Rural Agency For Sustainable Development Engineers Without Borders at the University of California, Davis (EWB-Davis) is a chapter of EWB-USA, a non-profit organization that partners with communities in developing countries to implement sustainable technologies that will improve the quality of life. The Rural Agency for Sustainable Development (RASD) is a community-based, nongovernmental organization (NGO) located in Nkokonjeru, Uganda that has partnered with EWB-Davis since 2006. RASD was established in 2000 by Nkokonjeru locals with a mission to educate local citizens in matters such as sanitation, drinking water treatment, agriculture, hygiene, and computer and vocational skills.

\section{Assessment}

Working within the EWB-USA project process (see Figure 1 for our interpretation of the process), EWB-Davis conducted an assessment trip (Dec. 29, 2006 to Jan. 10, 2007) to visit Nkokonjeru and the surrounding communities as a result of direct project request from RASD. There were three principal goals for the assessment trip: 1) develop a relationship with the community partner, RASD; 2) complete water quality analysis of various drinking water sources; and 3) employ discussions/surveys to improve understanding of the local needs and desires, as well as the community context and resources in which projects would be implemented. EWB-Davis and RASD had limited communication prior to the assessment trip although RASD had clearly indicated that drinking water treatment was a top priority and in line with EWB-Davis's skills set. Over the course of the assessment trip, EWB members spent 12 days touring ten rural villages with RASD members. In each village, EWB-Davis met first with community leaders and subsequently with a large group of local citizens to assess the local drinking water supply and community members' understanding of water treatment needs

\section{Water resources}

RASD identified drinking water quality and waterborne pathogens as an area of major concern for the region. Drinking water originated from a variety of sources including municipal piped water (only in Nkokonjeru proper), hand pumps, protected spring-boxes, collected rainwater, and surface water. The municipal piped water system was managed by a private operator with some financial support from the Ugandan government. The piped water was untreated and tested bi-annually by the private operator. The results demonstrated the water to be of high quality ( 2 and 0 CFU/100 mL total and fecal coliforms, respectively, in the most recent test). However, connections and usage charges are expensive and only function sporadically, and it was common for the distal connections to run dry during frequent water shortages. The system has been unreliable, some years being out of service from months, and under several operators has failed to ever be a self-supporting business.

Owing to these limitations, the vast majority of the region's water, particularly outside the town center, came from protected springs, hand pumps, or surface water. The region has two wet-dry cycles each year, and just after the wet periods, the springs produce sufficient water, however collection lines can be quite long. During the dry period, spring water becomes less available and in some cases disappears entirely. Additionally, some springs were reported to shift over time, causing the protected spring outlet pipe to be ineffective in spite of ample flow elsewhere. Long lines, shifting springs, and decreased flows during the dry period were all reported to cause households to become increasingly reliant on surface water during certain times, and although surface water quality had not previously been tested, it was found to be considerably worse quality than the springs and municipal system.

Water Quality Testing 
Uganda uses WHO guidelines for national drinking water standards. Urban systems have to comply with these standards but rural systems do not ${ }^{22}$. EWB-Davis team tested thirteen water sources for inorganic constituents and microbial contaminants, as well as subsequent laboratory testing (after return to UC Davis) for elemental concentrations in the ten villages they visited.

Limited supplies and laboratory equipment restricted the analysis of fecal indicator bacteria by using International Organization for Standardization (ISO) standards 9308-1:1990 (Membrane filtrations) or 9308-2:1990 (multiple tube). In the field, water microbial analysis was conducted using $3 \mathrm{M}^{\mathrm{TM}}$ Petrifilm ${ }^{\mathrm{TM}}$ E. coli/Coliform Count Plate (St. Paul, MN). Plates were able to distinguish between E. coli and other coliform organisms. Triplicate analysis was conducted for the detection of E. coli/Coliforms. Petrifilms were incubated for $24 \mathrm{hr} \pm 2$ $\mathrm{hr}$ at $30^{\circ} \mathrm{C} \pm 1{ }^{\circ} \mathrm{C}$. Plates were read shortly after incubation.

The microbial drinking water quality is conventionally determined for a $100 \mathrm{~mL}$ sample, where the EPA drinking water standard and the WHO goal is 0 coliforms $/ 100 \mathrm{~mL}$. The $3 \mathrm{M}$ Petrifilm required only $1 \mathrm{~mL}$ of water for analysis, which by dilution still allowed for quantification of low quality water, however it did not allow for quantification of high quality waters (i.e. $<30 \mathrm{CFU} / 100 \mathrm{~mL}$ ). The bacterial count that was read from the Petrifilm was multiplied by ratio of 100 to 1 in order to compare results to a $100 \mathrm{~mL}$ sample analysis.

To accurately quantify field collected water samples' bacterial concentrations, samples were plated (no dilution); the Petrifilms were incubated on a person's back during transport and were transferred to the incubator once back at their host site (Figure 2). Water samples were also collected and brought back to the host site, from which an un-diluted and diluted (1/10 original concentration; phosphate buffered dilution water) were plated in triplicate and incubated.

\section{Microbial Results}

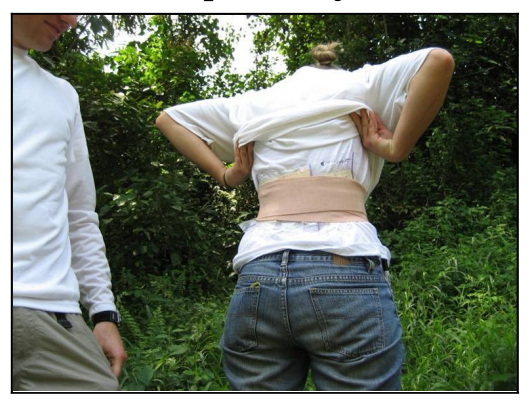

FIGURE 2

HUMAN INCUBATOR

Water quality analyses were performed on the assessment trip during the end of the wet season for thirteen different water sources. 3M Petrifilm E. coli and total coliform results, summarized by water source, are shown in Table 1 . Half of village water supplies tested positive for $E$. coli, and detected concentrations ranged from $30-1470 \mathrm{CFU} / 100 \mathrm{~mL}$, which is an indication of poor quality ${ }^{23}$. All water sources, except for one protected spring (P.S.), tested positive for additional non-E. coli coliforms, and the median concentration was 435 CFU/100 mL. No E. coli was detected in the protected springs, while, as expected, surface waters contained noticeably more E. coli and total coliforms than other water sources. One of the jerrycans, which are routinely used for water collection, was tested to determine whether post-collection contamination was occurring. Results showed that there was an increase in total coliforms at the bottom of the jerrycan, which remained moist after emptying, but that E. coli were not being transferred via the jerrycan (non-detect for both sections). 
TABLE 1. SUMMARY OF RESUlTS FROM WATER QUALITY TESTING DURING THE 2006/2007 ASSESSMENT TRIP. FULL DATA AVAILABLE IN SUPPLEMENTAL INFORMATION.

\begin{tabular}{|l|c|c|c|}
\hline Water source type (n) & Metric & $\begin{array}{c}\text { E. coli (CFU/100 } \\
\text { mL) }\end{array}$ & $\begin{array}{c}\text { Total coliform } \\
(\text { CFU/100 mL) }\end{array}$ \\
\hline Surface water - lakes and streams (5) \\
\hline & median & 30 & 470 \\
\hline & maximum & 1470 & 2000 \\
\hline Unprotected springs (2) & Median & 50 & 530 \\
\hline \multicolumn{3}{|c|}{} \\
\hline Protected spring/hand pump (6) & N.D. & 230 \\
\hline & Median & N.D. & 930 \\
\hline
\end{tabular}

Participatory Assessment of Community Needs

During the assessment trip, EWB-Davis had the opportunity to meet with the local leaders, attend town meetings, and visit private residences. EWB-Davis attended a council of regional leaders at one central meeting, attended meetings with local town councils/leaders (four villages) and their citizens in the more remote villages (three villages; 25-35 participants), select individuals/families (two villages), and visited special interest facilities (three villages) including a demonstration farm, a saving co-op, and two schools. Owing to the limited time available, formal survey techniques such as a transect walk were not employed, however in each meeting, participant were asked about drinking water and sanitation practices, including water collection, water consumption, and health. Participants were also asked to share any concerns they had or areas that they felt could potentially be addressed through a partnership with EWB-Davis.

In spite of the less structured survey technique employed, several themes were repeated; more detailed survey results are available in supplemental information. Households that used surface water reported that they allowed the water to stand for several minutes to allow particulate matter to settle and then transferred the remaining into a second container. Drinking water treatment, although widely understood as needed, was not commonly practiced, with boiling the only treatment that was mentioned. While the local primary schools stated that they routinely boiled water (though not always sufficient volumes), among households it was not a common practice (typically 20-30\% claimed they 'often' boiled drinking water). RASD volunteers thought that most people did not boil their water because of the cost/effort required to obtain wood rather than lack of information, although this was not confirmed by any external party.

EWB-Davis presented various potential POU water treatment systems to a group of RASD leaders and volunteers and fully discussed what attributes of each system were attractive or negative. EWB-Davis has extensive experience with biosand filters ${ }^{14}$ and expected that to be among the systems considered for implementation. RASD volunteers thought that chlorination, solar UV disinfection, and clay pot filtration were good potential treatment options, but saw biosand filters as too complex to implement. In spite of EWBDavis confidence in biosand filters, the relationship with RASD was too brief to attempt to change minds about biosand filters. The assessment trip provided sufficient information to enable the design of a test program for the four water technologies with which RASD felt comfortable. 
TABLE 2. SUMMARY OF COMMUNITY SURVEYS AND RASD ASSESSMENT CONDUCTED DURING THE WINTER 2007 ASSESSMENT TRIP.

\begin{tabular}{|c|c|c|c|}
\hline Village/entity & Date & Dialogue & Demonstrations \\
\hline Town council meeting & $12 / 30 / 2006$ & $\begin{array}{c}\text { Mayor and regional leaders expressed } \\
\text { concerns on water (quantity and } \\
\text { quality). sanitation (lack of toilets and } \\
\text { rubbish disposal) }\end{array}$ & - \\
\hline RASD resource center & $12 / 31 / 2006$ & $\begin{array}{l}\text { Discussion on RASD interests and } \\
\text { current projects; discuss possible EWB } \\
\text { Davis-RASD partnership areas }\end{array}$ & $\begin{array}{l}\text { Connection to municipal piped } \\
\text { water - not working (typical) }\end{array}$ \\
\hline Naziwanga & $12 / 31 / 2006$ & $\begin{array}{l}\text { Village with } 300-500 \text { inhabitants } \\
\text { Meet with village leaders and leam that } \\
\text { few boil water but } 80 \% \text { have pit latrines } \\
\text { (flood during rainy season) } \\
\sim 30 \% \text { claim to boil water }\end{array}$ & $\begin{array}{c}\text { Tested stream water source } \\
\text { House visits to see rain water } \\
\text { harvest units }\end{array}$ \\
\hline Kigaya & $1 / 1 / 2007$ & $\begin{array}{l}\text { Village on lake Victoria with } \sim 2500 \\
\text { inhabitants. Meet with } \sim 35 \text { villagers and } \\
20 \% \text { claim to boil water }\end{array}$ & $\begin{array}{l}\text { Community bathroom, but many } \\
\text { people cannot afford the user fee }\end{array}$ \\
\hline Mayirikiti & $1 / 2 / 2007$ & $\begin{array}{c}\text { Village with } 500-800 \text { inhabitants } \\
\text { Meet with village leaders and leam that } \\
30-50 \% \text { boil water - Meet with } \sim 30 \\
\text { citizens }\end{array}$ & $\begin{array}{l}\text { See two household latrines to } \\
\text { provide spectrum of conditions: } \\
\text { Drinking water sources tested: } \\
\text { two springboxes }\end{array}$ \\
\hline Kiremba & $1 / 3 / 2007$ & $\begin{array}{l}\text { Village with } 300-400 \text { inhabitants } \\
\text { Did not formally meet with town } \\
\text { members }\end{array}$ & $\begin{array}{l}\text { Drinking water sources tested: } \\
\text { springbox, handpump }\end{array}$ \\
\hline Ssenyi Landing & $1 / 3 / 2007$ & $\begin{array}{l}\text { Port town (L_. Victoria)w/ } \sim 5000 \\
\text { inhabitant }\end{array}$ & $\begin{array}{c}\text { Public toilets: Urine diversion } \\
\text { eco-san toilet, UNDP pour-flush } \\
\text { toilet Have large rainwater } \\
\text { harvesting system }\end{array}$ \\
\hline Nkokonjeru & $1 / 4 / 2007$ & $\begin{array}{l}\text { Meet with town leaders. } \\
\text { Discuss municipal piped water supply }\end{array}$ & $\begin{array}{l}\text { Visit municipal water operator } \\
\text { headquarters - cannot pump } \\
\text { enough water to meet demand }\end{array}$ \\
\hline Mullaje & $1 / 5 / 2007$ & Meet with one progressive household & $\begin{array}{c}\text { Tour demonstration farm with } \\
\text { progressive agriculture and } \\
\text { sanitation practices } \\
\text { Tested springbox water } \\
\end{array}$ \\
\hline Ndolwa & $1 / 6 / 2007$ & $\begin{array}{l}\text { Did not formally meet with town } \\
\text { members }\end{array}$ & Springbox - now dried \\
\hline Buira & $1 / 7 / 2007$ & $\begin{array}{c}\text { More than } 400 \text { inhabitants } \\
\text { Met with village leaders and select } \\
\text { households }\end{array}$ & $\begin{array}{l}\text { Drinking water sources tested: } \\
\text { springbox and unprotected spring }\end{array}$ \\
\hline RASD resource center & $1 / 8 / 2007$ & $\begin{array}{l}\text { Discuss drinking water point of use } \\
\text { treatment option with RASD }\end{array}$ & - \\
\hline $\begin{array}{c}\text { Youth Association for } \\
\text { Rural Development } \\
\text { (YARD) }\end{array}$ & $1 / 8 / 2007$ & $\begin{array}{l}\text { Agricultural demonstrations, large in- } \\
\text { ground rainwater harvesting unit } \\
\qquad(15,000 \mathrm{~L})\end{array}$ & $\begin{array}{l}\text { Visit several households that } \\
\text { have leamed from YARD }\end{array}$ \\
\hline Nkokonjeru & $1 / 9 / 2007$ & $\begin{array}{c}\text { Two local schools - concentrate on } \\
\text { student illnesses }\end{array}$ & - \\
\hline
\end{tabular}

\section{Implementation}

Following the assessment trip, student teams spent six months during spring 2007 designing and testing potential POU systems at UC Davis. To ensure that the POU systems would be maintained after implementation and for the spread of the technologies within the region, project design focused on education and outreach on all aspects of the technology, first to our community partner, RASD, and ultimately to the community of Nkokonjeru. Project leaders of EWB - Davis were in constant communication via email and Skpye with leaders of RASD to obtain feedback on project design, education material, and translation of reading material into Luganda. The objectives for the summer 2007 implementation trip were to implement four low-cost POU water treatment systems at RASD, to monitor the quality of the treated water, assess the ease of use of each system, and to provide information to the community on the subject of water-borne diseases, post-contamination and proper use of technologies.

\section{Point-of-Use (POU) Water Treatment Systems}




\section{Filtron (Clay Pot Filter)}

Filtron clay pot filters (Figure 3) are produced by independent contractors under the direction of the international organization Potters for Peace (Bisbee, AZ). Filtron clay pots provide both physical and chemical treatment. The physical filtering characteristic makes it suitable for turbid surface water sources, with consequent increases in maintenance and reduced life of the filter pot. The clay pots are made out of $60 \%$ dry pulverized clay and $40 \%$ screened sawdust mixture (mixtures approximate and vary with material supplies). The dimensions of the filter are $31 \mathrm{~cm}$ in diameter, $24 \mathrm{~cm}$ high, and $7.1 \mathrm{~L}$ volume. Pots are fired at $887{ }^{\circ} \mathrm{C}$ and then impregnated with colloidal silver. The pore size of clay pots is approximately 1 $\mu \mathrm{m}$. The filter sits inside a $20 \mathrm{~L}$ bucket that is equipped with a spigot. A plastic lid is placed on top of the bucket. The flow rate for the pot is 1 to 2 liters per hour 9 .

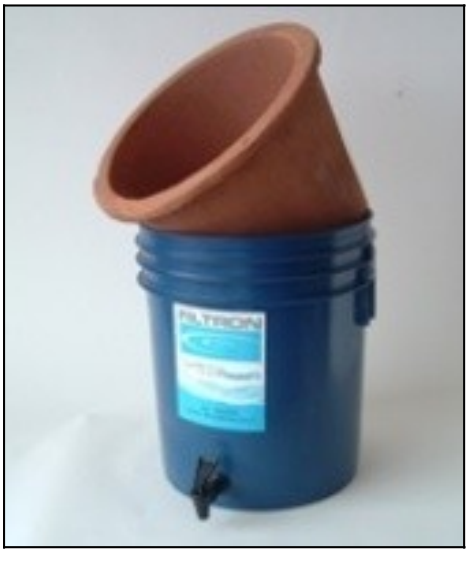

FIGURE 3

FILTRON CLAY POT PLACED ON A PLATICD RECEPTACLE

The clay pots used in Uganda were manufactured in a new facility in Kenya. Kenya's Potters for Peace representatives Reynaldo Diaz and Kaira Wagoner joined the EWB-Davis team for the installation of the pots. They had been in Kenya specifically to establish the new Filtron factory. Their assistance added support for the overall water treatment implementations and gave them the opportunity to assess the possibility of a future plant in Uganda.

\section{Results}

Prior to analysis, water from the protected springs was filtered through the six clay pots twice. This filtering was done to ensure that the filters were operating properly and to remove any dirt that may have come into contact with the clay pots during transport. Clay pots were used to treat water from a protected spring and surface water. The treated water was tested at three different detention times for the protected spring water (i.e. first flush, 24 hours later, and 6 days later). The $3 \mathrm{M}^{\mathrm{TM}}$ Petrifilm ${ }^{\mathrm{TM}}$ E. coli/Coliform Count Plate and the High Sensitivity Coliform Count Plate were used to test microbial quality of the water before and after treatment. Triplicate analysis showed no detection of E.coli or total coliforms after the three detention time (Figure 4). 


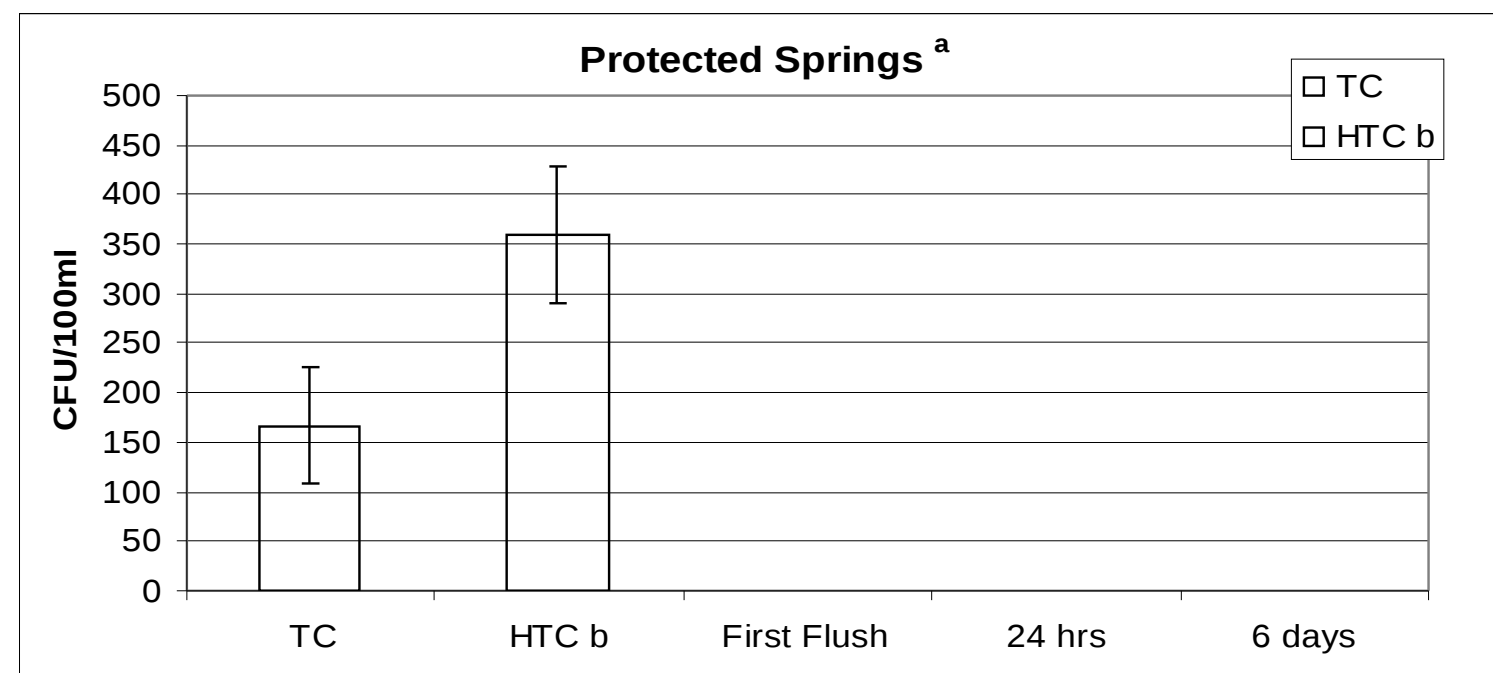

${ }^{a}$ Water from the protected spring was collected using jerrycan \# 2 on August 21, 2007; ${ }^{\mathrm{b}}$ Total coliforms detected using High Sensitivity Coliform Count Plate (H.S.C)

\section{FIGURE 4}

MICROBIAL RESULTS OF WATER COLLECTED FROM THE PROTECTED SPRING AND TREATED WITH FILTRON POT.

The surface water had a higher concentration of E. coil and total coliform than the protected spring water. The treated water was tested after a detention of 24 hours and 6 days. The High Sensitivity Coliform Count Plate showed detection of total coliform after the 24 hour detention time. There was no detection of total coliform or E. coil with the remaining detention time (Figure 5)

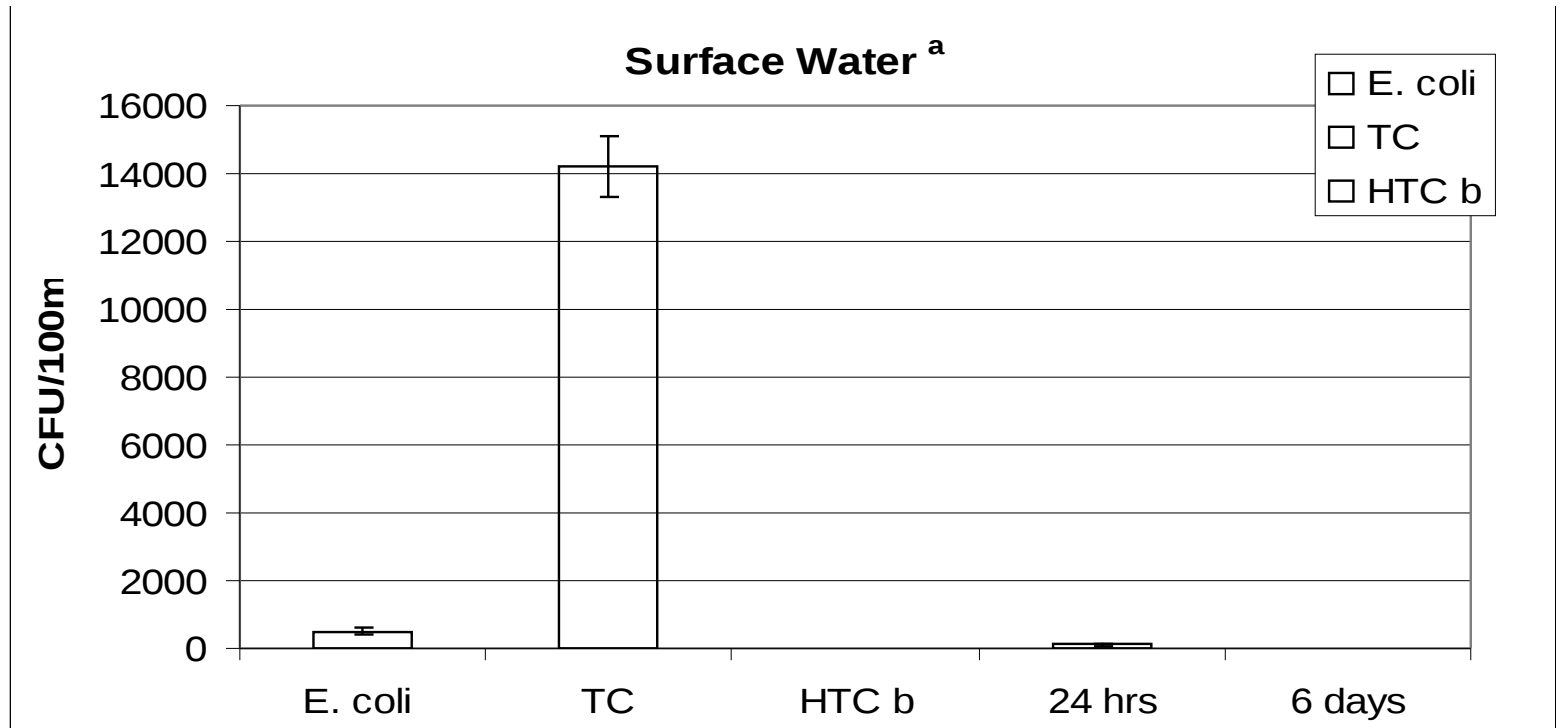

\footnotetext{
${ }^{\text {a }}$ Water from the surface was collected using jerrycan \# 1 on August 22, 2007; one clay pot was used for the treatment of water from the surface; b H.S.C: too numerous to count (TNTC);

FIGURE 5

MICROBIAL RESULTS OF WATER COLLECTED FROM THE SURFACE AND TREATED WITH FILTRON POT.
} 


\section{Solar Water Disinfection (SODIS)}

The SODIS is a POU treatment that uses the sun's UV rays (wavelength $320-400 \mathrm{~nm}$ ) to destroy pathogenic microorganism ${ }^{5}$. The sunlight also increases the temperature within the plastic bottle which increases the rate of disinfection. The Swiss Federal Institute for Environmental Science and Technology (EAWAG) and EAWAG's Department of Water and Sanitation in Developing Countries (Sandec) has done extensive research on the treatment effectiveness of SODIS. Previous research has shown that temperatures above $50^{\circ} \mathrm{C}$ increase the disinfection efficiency by 3 fold.

Bottles made from polyethylene terephthalate (PET) plastic were collected during the first two

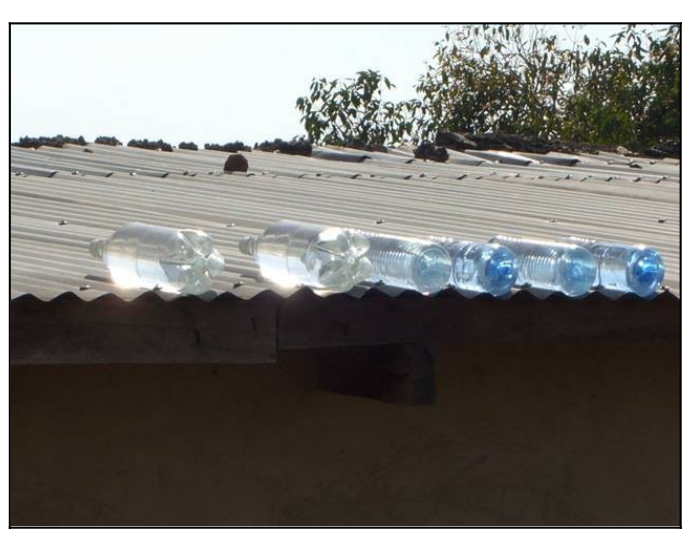

FIGURE 6

SODIS TREATMENT: COKE, LIGHT BLUE RWENZORI, AND DARK - BLUE SIPI BOTTLES weeks of the implementation trip. A funnel was used to fill the bottles with water from the protected springs. Bottles were first filled with water from a protected spring three-fourths of the way and then shaken for 20 seconds. After shaking, the bottles were filled completely with water. Bottles were placed on top of RASD's tin roof (Figure 6). Water was tested after $6.5 \mathrm{hr}$ of sunlight exposure. Bottles were then placed inside RASD's facility and tested the following morning to determine if bacterial re-growth had occurred. Bottles were placed back on the roof for another 6.5 hours and retested. In a second set of experiments the same test was performed to treat surface water using SODIS. Based on the first set of data, different bottles were chosen for surface water treatment. Treated surface water was tested after $6.5 \mathrm{hr}$ and again on the second day.

\section{Results}

The first day experiments that treated the protected spring water (Figure 7) took place on a day that was mostly sunny. Both the Coke and Rwenzori (local bottled drinking water) bottle had no detection of coliforms after different times of treatment. The Coke bottles are preferred over the Rwenzori drinking water bottle because of its larger volume. The dark blue-tinted Aqua Sipi (another local bottled drinking water) bottle did not treat water as effectively and there were some viable bacteria left that could continue to multiply. 


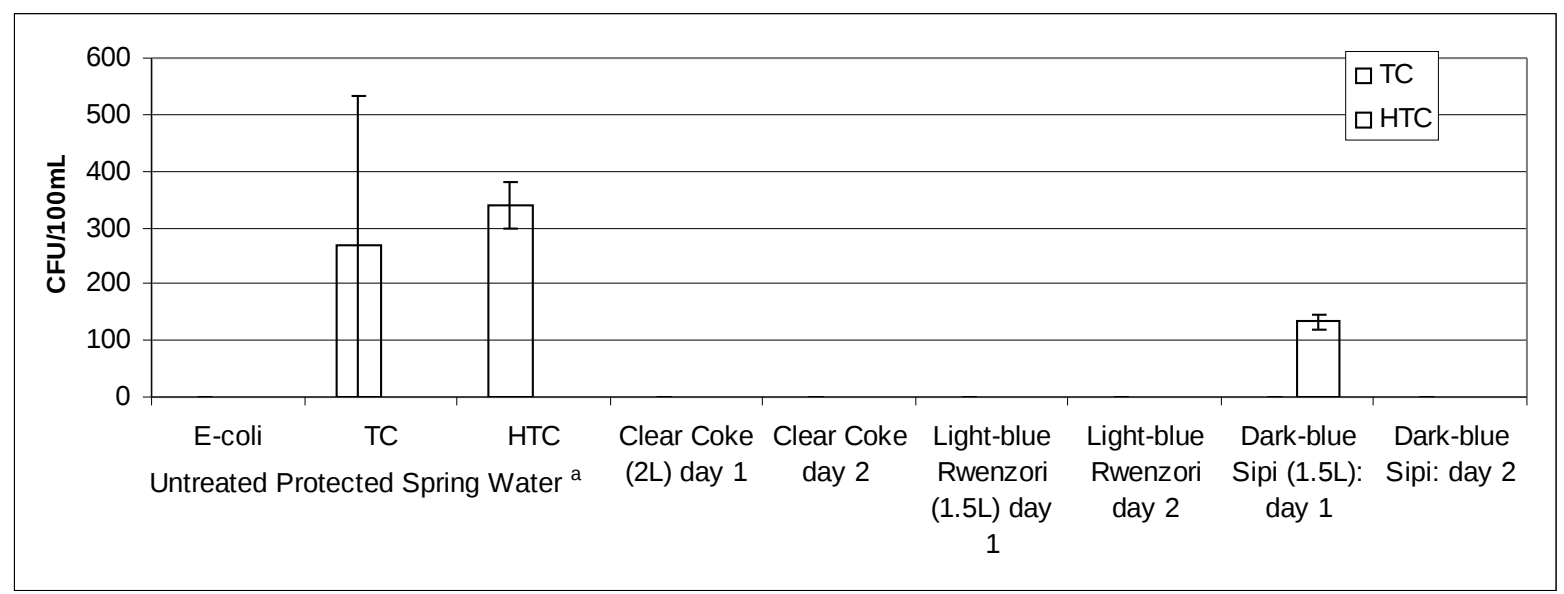

${ }^{\text {a }}$ Water from the protected spring was collected using jerrycan \# 1 on August 21, 2007

\section{FIGURE 7}

\section{MICROBIAL RESULTS OF WATER COLLECTED FROM THE PROTECTED SPRING AND TREATED WITH SODIS}

The second set of experiments that tested treated surface water (Figure 8) took place on a partly cloudy day. The treatment of water took a longer time on partly cloudy days. There was a higher concentration of total coliforms detected in the $2 \mathrm{~L}$ bottles after the $6.5 \mathrm{hr}$ sunlight exposure. Both the Coke and Fanta bottle had a volume of $2 \mathrm{~L}$. Less sunlight reduced UV and resulted in dose lower temperatures. These factors affected the treatment effectiveness for the larger volume on the second experiment. UV light has to travel further through a larger bottle. The light-blue Rwenzori bottle, with a volume that was smaller than the soda bottles, had the best treatment of all three bottles used in the tests.

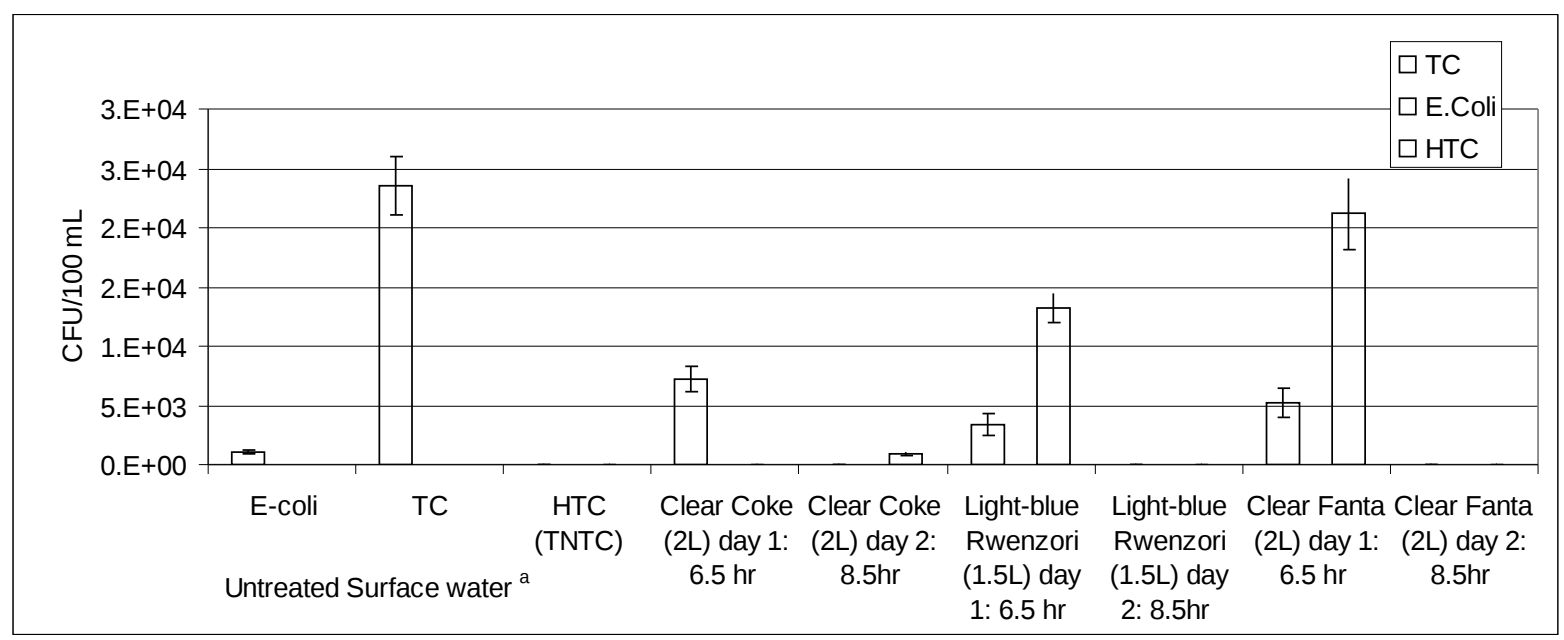

${ }^{\text {a }}$ Water from the surface was collected using jerrycan \# 1 on August 28, 2007; water was not filtered; partly cloudy conditions during the entirety of experiment

FIGURE 8

MICROBIAL RESULTS OF WATER COLLECTED FROM THE SURFACE AND TREATED WITH SODIS 


\section{WaterGuard (Chlorine disinfection)}

Population Service International (PSI) produces and distributes WaterGuard (Figure 9) in Uganda and the same product under different names throughout the developing world. WaterGuard is a liquid chemical water treatment that consists of $1 \%$ sodium hypochlorite. Sodium hypochlorite treatment provides residual disinfection capability. A $150 \mathrm{~mL}$ bottle can treat $1000 \mathrm{~L}$ of water. The disadvantage to this POU treatment system is that sodium hypochlorite does not deactivate Cryptosporidium or Giardia lamblia. It also retains an odor and taste. Chlorine treatment is also less effective with highly turbid waters.

WaterGuard treatment was applied to the two different water sources and the treated water tested. The two receptacles were each filled with $20 \mathrm{~L}$ of water from the protected spring and surface water respectively. A cap-full ( $3 \mathrm{~mL})$ of WaterGuard was added to each receptacle. The water in each receptacle

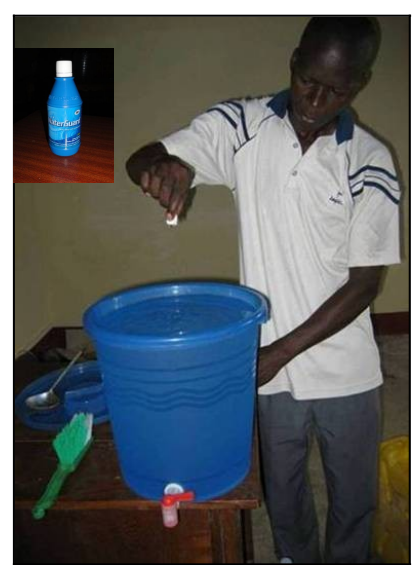

FIGURE 9 RASD EMPLOYEE USING WATERGUARD TO TREAT 20 L OF WATER was stirred and allowed to sit for 30 minutes. The protected spring water was tested after the 30 minute treatment. The surface water was tested at two detention times (i.e. $30 \mathrm{~min}$ and 3 days) because it was anticipated that the 30 minutes would not be a sufficient time because the water was cloudy (turbid).

\section{Results}

There was no detection of $\mathrm{E}$. coli or total coliforms using the $3 \mathrm{M}^{\mathrm{TM}}$ Petrifilm ${ }^{\mathrm{TM}} \mathrm{E}$. coli/Coliform or the High Sensitivity Coliform Count Plate (Figure 10). Despite the turbidity of the surface water, 30 minutes was a sufficient amount of time for complete treatment.

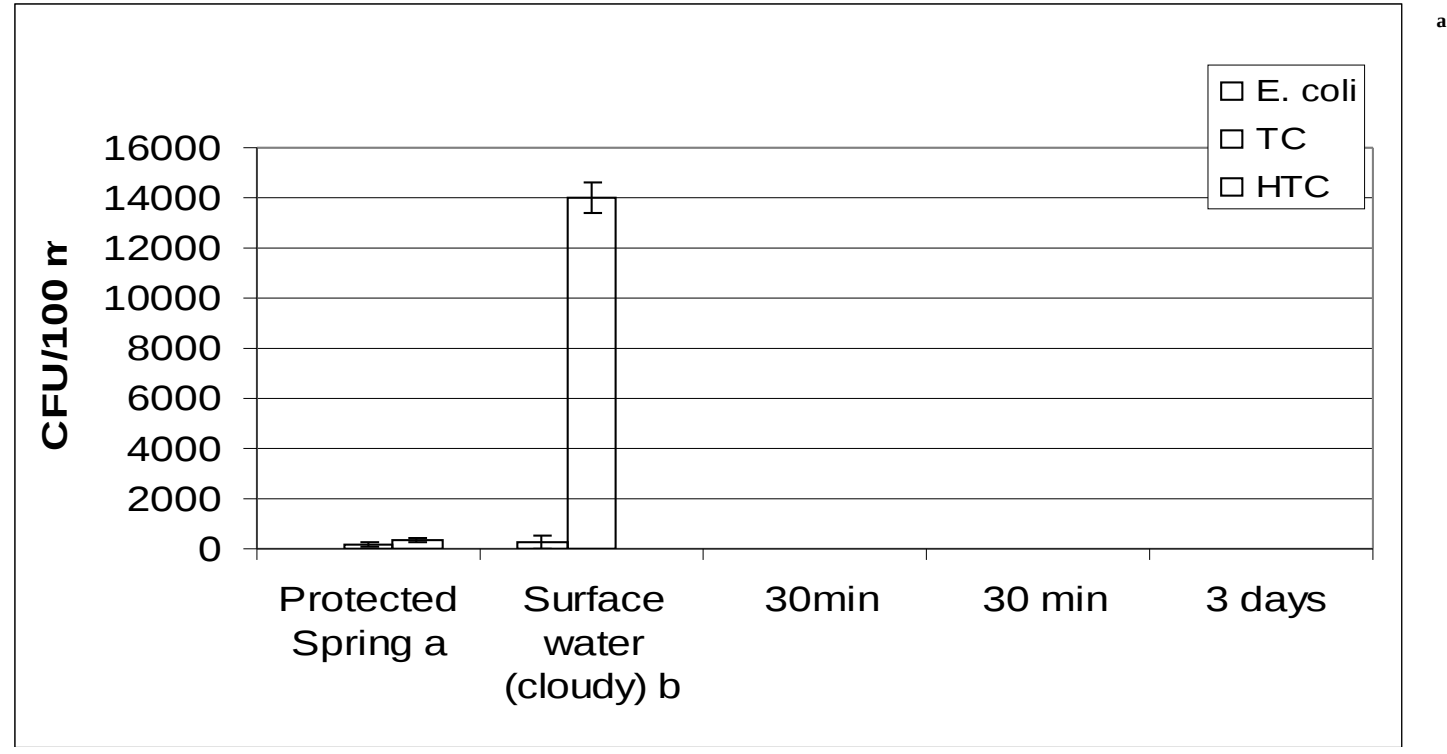

Water from the protected spring was collected using jerrycan \# 2 on August 21, 2007

b Water from the surface was collected using a jerrycan, that was only used for WaterGuard treatment, on August 28, 2007

FIGURE 10

MIRCOBIAL RESULT OF TREATED PROTECTED SPRING AND SURFACE WATER USING WATERGUARD 


\section{SilverDyne (colloidal silver)}

SilverDyne, supplied by the World Health Alliance International (Las Vegas, NV), is a colloidal silver based solution that consists of clustered double distilled water compound ${ }^{17}$. Colloidal silver are fine particles of silver held in suspension. Colloidal silver works by disabling the enzymes in viruses, pathogens, bacterium, and fungi, which leads to their death $^{8}$. SilverDyne is not consumed in this process so it also provides residual disinfection capacity.

SilverDyne treatment was applied to the two different water sources and the treated water tested. The two receptacles were each filled with $20 \mathrm{~L}$ of the water from the protected spring and surface water respectively. One drop of SilverDyne was added for every two liters of water. For very dirty (turbid) water, 2 drops were added for every liter. The water in each receptacle was stirred and allowed to sit for 30 minutes. The protected spring water was tested after the 30 minute treatment. The surface water was tested at two detention times (i.e., 30 min and 3 days) because it was anticipated that the 30 minutes would not be a sufficient time when the water was cloudy (turbid).

\section{Results}

The protected spring water had a low concentration of coliforms 30 minutes after treatment. It is hypothesized that a slightly longer detention time would eliminate all coliforms, since the more contaminated turbid water tested clean after 3 days. The surface water collected for this experiment had the highest detection of E. coli and total coliforms of all the other surface water samples that were collected. E. coli and total coliforms were both detected after treatment of the surface water. The allocated time for treatment for the surface water, 30 minutes, was not sufficient. A detention time of three days was a sufficient amount of time for treatment (Figure 11).

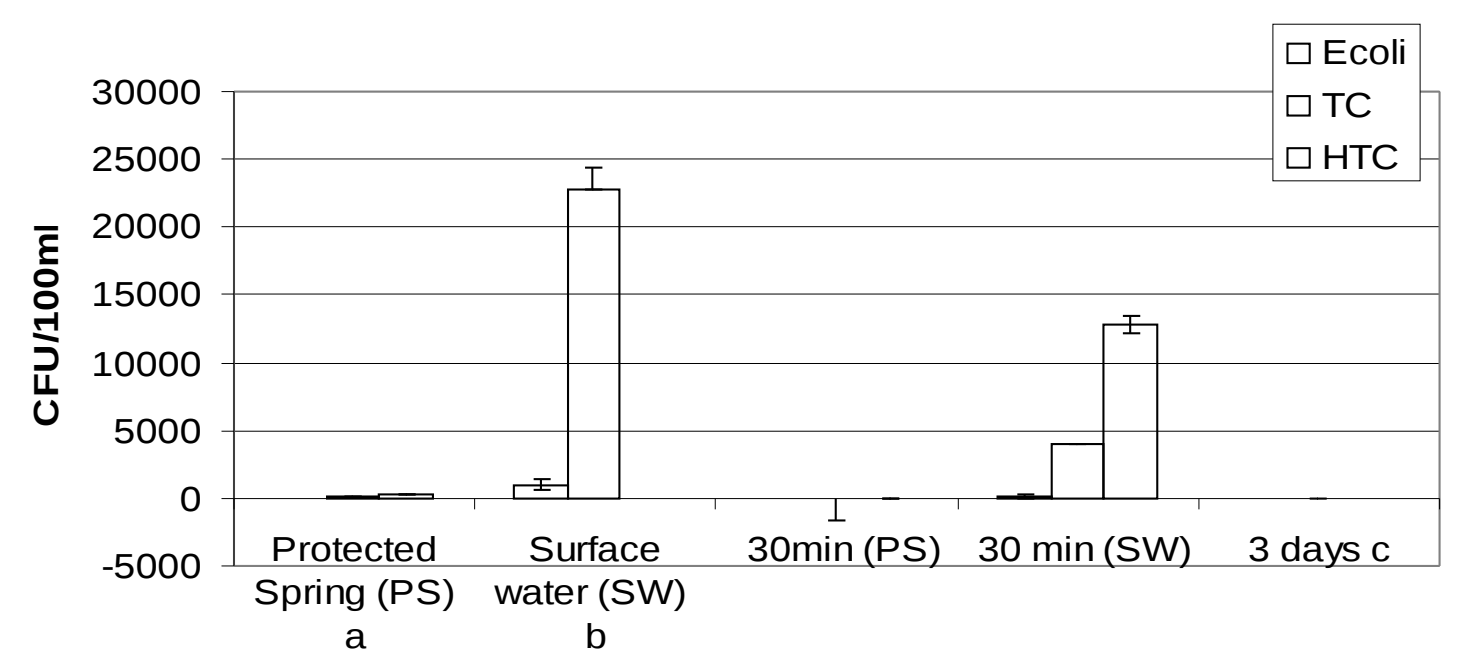

a Water from the protected spring was collected using a dirty jerrycan on August 21, 2007; b Water from the surface was collected using a jerrycan, which was only used for SilverDyne treatment,on August 28, 2007; c No detection of e.coli/total coliforms for both protected and surface treated water

FIGURE 11

MIRCOBIAL RESULT OF TREATED PROTECTED SPRING AND SURFACE WATER USING WATERGUARD 
TABLE 3: SUMMARY OF ATTRIBUTES OF POU TREATMENT TECHNOLOGIES

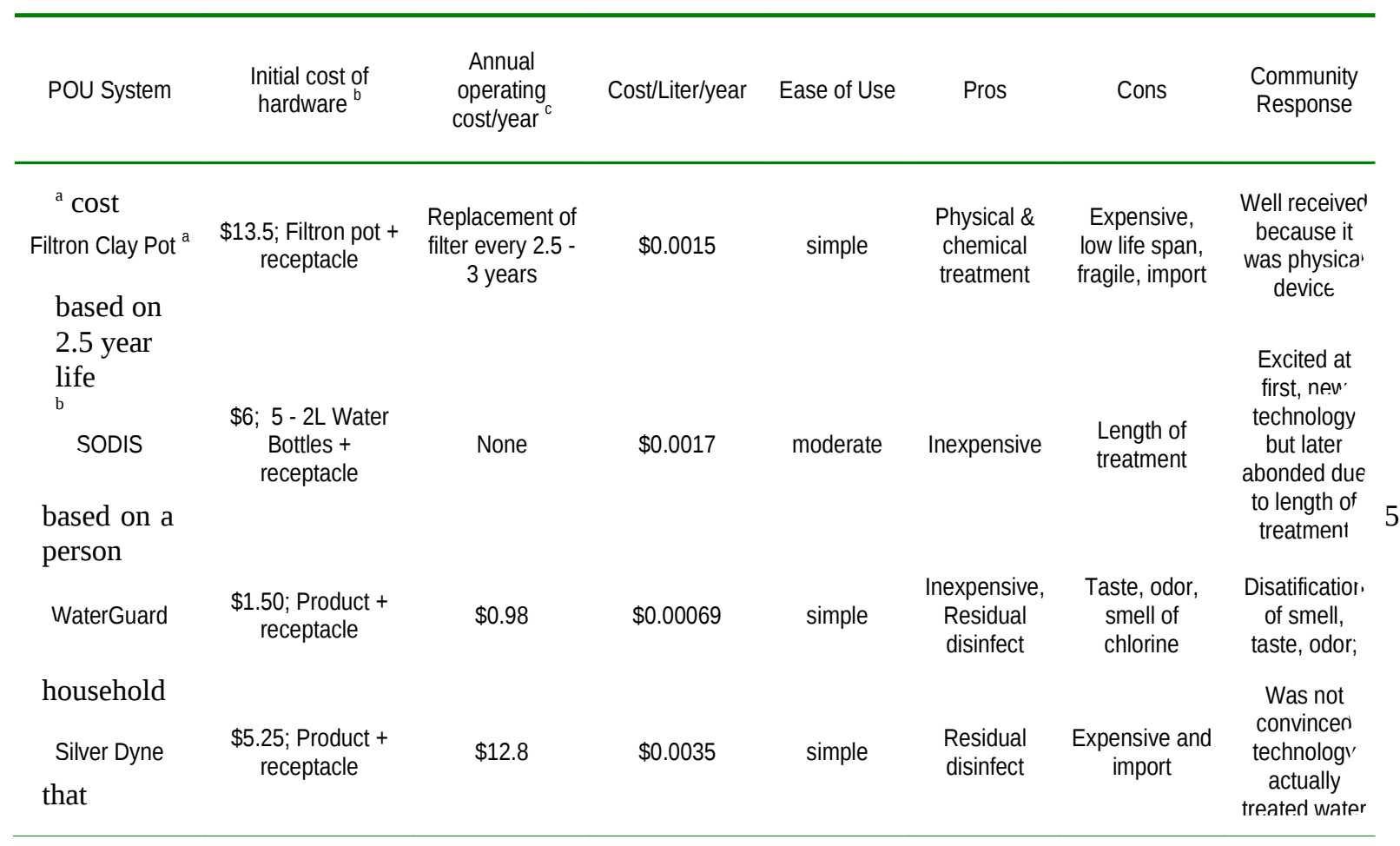

consumes 2 liter/day/person

${ }^{\mathrm{c}}$ all systems had same cleaning maintenance, cost not included

\section{Sustainability and Participation: POU Water Treatment Systems}

Table 3 summarizes the cost of each system and their attributes. It was recommended for all POU systems that water be filtered before treatment for highly turbid water. The life-span of the Filtron clay pots is approximately two years with the treatment of highly turbid water. Highly turbid water decreases the flow rate and also increases maintenance frequency of the clay pot. It is hypothesized that clay pots would have a longer life-span if turbid water was not filtered on a continuous basis. Filtron can treat approximately 7,500 liters of water during its useful life.

SODIS treatment is a good system for areas that receive substantial amounts of sunshine and low turbidity water ( $<30 \mathrm{NTU}$ ) but is inefficient and difficult to define with regions with varying climate. The climate within central Uganda consists of two dry (December to February, June to August) and one rainy season ${ }^{3}$. The dry season still gets a large amount of rainfall. To ensure proper disinfection during cloudy days, the bottles needed to be on the roof for 24 hours. Additional time was needed for the water to cool down after being in the sun. $1.5 \mathrm{~L}$ plastic water bottles could be easily found in Nkokonjeru but $2 \mathrm{~L}$ were less common. Larger bottles were available in shops in Mukono which was 45 min away by car. Families had a choice to purchase more $1.5 \mathrm{~L}$ bottles to fulfill their water demand or purchase less by traveling to obtain the larger bottle.

WaterGuard was sold in urban Uganda. Cases of WaterGuard could be purchased and sold within the local Nkokonjeru market. A bottle of WaterGuard could last for three months for a family of five. SilverDyne was not available in Uganda but efforts were being made to develop marketing and distribution. SilverDyne had the same residual benefits as the WaterGuard treatment, with the added benefit that SilverDyne has no distinct smell or taste aFter treatment. A single bottle can treat up to 1200 liters of water, if properly used. 
EWB-Davis, along with the members of RASD, held educational seminars to address water-borne disease, post contamination and proper use of each POU water treatment systems. Each of these systems incorporated a bucket with a lid and spigot to prevent post contamination. Each of the technologies was implemented in two different homes. Members of the RASD team visited each family once a month to survey the acceptability, test the water quality of the product and ascertain long-term effectiveness of each technology.

\section{Cultural Acceptability and Project Revision}

All four treatment systems worked effectively with minimal to no detection of coliforms. Of the four technologies, only the Filtron clay pots were used continuously throughout the year. The SODIS treatment system was abandoned early in the implementation experiment because treatment took too long, and the community never gained faith in the quality of the finished water. Although two Peace Corp Volunteers assigned to the community used SODIS as their main water treatment, the community still lacks faith in the SODIS system. Both chemical treatments were used for half the year. The families with the WaterGuard complained of a chlorine taste and smell. SilverDyne treatment did not receive complaints in regard to taste and odor and overall had good water quality results. Although the chemical treatment systems were demonstrated to be effective through water quality analysis, people still did not accept that the treated water was clean; they simply preferred a system where they could physically understand the process. Accordingly, Filtron clay pots received high reviews in cultural acceptance but the system decreased in treatment efficiency after 9 months of use. Filtron pots were the most expensive initial investment system of all water treatment systems implemented, but remained culturally acceptable because people could observe turbidity removal between the raw and finished water. In addition, families with the pots stated that they liked that they could show family members, friends and neighbors a device that treated water.

It was determined over the remainder of the year-long assessment of the POU systems that Filtron Clay Pots were in high demand. The manufacturer of the pots determined that manufacturing of pots would have to be located in the capital Kampala and would take at least a year to implement. After discussion with RASD members, it became clear that the additional costs of transportation for pots would not be economical for the community. With full understanding that the local communities preferred a treatment system that was more physically based and over a year to gain confidence in EWB-Davis, RASD reconsidered biosand filters after it was determined that the Filtron pots were not going to be available in the region. The UC Davis research project of biosand filters in Kenya demonstrated that building round molds for biosand filter casings, although more efficient in concrete use, was difficult to achieve. RASD and EWB-Davis elected obtain a biosand filter mold made from the CAWST design which is square ${ }^{1}$. After finding local crushed sand for the filter medium, two pilot biosand filters were built (i.e., one at RASD and another at a local health clinic). The water quality was assessed over the following year and cultural surveys were conducted to determine the acceptability of the device. Subsequently, RASD obtained a grant from the U.S. Embassy in Kampala to support the construction of fifty more biosand filters in Nkokonjeru for HIV/AIDS impacted families.

\section{Monitoring and Evaluation of Biosand Filters}

RASD manufactured and placed over fifty biosand filters during 2009-2010. In the summer of 2010 EWB-Davis along with RASD surveyed 30 of the implemented filters. The goal of the survey was to determine functionality of filters, customer satisfaction, and health 
improvements due to the adoption of the technology. Both RASD and users of the filters were questioned on issues varying from number constructed and overall project success to frequency of use, water source, frequency of illness among users and ease of use (see survey questions in supplemental information).

Although Survey responses indicated that users were happy with the filters in general, the respondents listed several issues and concerns with the filter performance and filter design (see Survey Response Data in supplemental information). Several issues were identified related to filter construction quality, with several users experiencing water seepage from the cement case, turbidity in the finished water, fragile spigots, and too small a collection vessel for the treated water. These quality issues were addressed through training exercises with RASD masons.

Microbial water quality testing was conducted for treated water at the biosand filter sites. The majority of filters effectively treated the water with the exception of the filters in the installed in an Nkokonjeru orphanage. High concentrations of total coliform were detected in treated water samples from the orphanage filters. Upon further examination, an error was found in the construction method of the biosand filters leading to insufficient treatment. The plastic tube, which drains the filtered water, was too long. While convenient for the user to distribute water to containers sitting on the floor, this had the unintended consequence of siphoning water out of the filter body, providing insufficient contact time with the filter medium, reducing or eliminating the viability of the biofilm, and compromising the efficiency of the filter. The problem was addressed and RASD technicians and field monitoring personnel were further trained about the proper construction of the biosand filters.

The issues demonstrated to RASD the ongoing need to monitor and evaluate the efficiency of the biosand filters to ensure proper operation of the technology. Without careful and timely monitoring and correction, minor issues, which would have escalated to major issues, would have gone unnoticed. The compromised filters would have eventually been abandoned, would bring into question the viability of properly functioning filters and could have compromised the POU program throughout the broader Nkokonjeru community.

\section{Conclusions}

Over a five year period, EWB - Davis worked with RASD to develop and implement sustainable POU water treatment systems. The project brings to light the necessity of working closely with the community to determine technologies that will be acceptable, rather than just trying to supply the most cost-effective solution. Without community acceptance, even viable programs will be abandoned in the long term. The community of Nkokonjeru rejected the implementation of chlorine treatment outright, although it is the most cost-effective, locally available approach available.

During the course of the project, the community gained confidence in EWB which allowed the implementation of a more complicated but more suitable technology which was originally rejected. Biosand filtration was successfully implemented despite the community's initial hesitance. The lack of marketing of the product has lead to the delay of manufacturing and sales.

Finally, regardless of the extent of initial training and education, it became apparent that there is no substitute for an ongoing relationship that can provide continued follow up on the full process of the filter supply and use chain. Otherwise, there can always be unintended consequences of modifications such as experienced with the drain tubes on the biosand filters. 
The major limitations of our efforts are related to the continued need for technical and financial capacity to sustain the biosand filter program. In addition to initial costs, lack of marketing to the general public and inadequate education operation remain major barriers to long-term project success. Increased training in operation and maintenance as well as long term marketing and microfinance will be necessary to drive project sustainability into the future.

\section{Acknowledgement}

The authors would like to acknowledge the director of RASD, Ignitius Bwoogi, for his leadership, without which this project would have been impossible. The authors would also like to thank the members and volunteers that support RASD, Jeannie Darby and the Department of Civil and Environmental Engineering at UC Davis for financial and technical assistance. Finally, the authors would like to thank the many groups and private donors whose generosity supported our work.

\section{References}

CAWST (2011). “Biosand Filter.” Retrieved May 4, 2011. http://www.cawst.org/en/themes/biosand-filter

CDC (2010). "Malaria." Retrieved December 7, 2010.

CIA (2008). "The World FactBook: Uganda." https://www.cia.gov/library/publications/theworld-factbook/geos/ug.html\#Econ Retrieved March 18, 2008.

Davis, J., A. Kang, et al. (2001). "How Important is Improved Water Infrastructure to Microenterprises? Evidence from Uganda." World Development 29(10): 1753-1767.

EAWAG (2008). SODIS. S. F. I. f. E. S. a. Technology, http://www.sodis.ch/Text2002/TTheMethod.htm.

Gadgil, A. (1998). "Drinking water in developing countries." Annual Review of Energy and the Environment 23: 253-286.

Kombucha. (2008). "C. Silver Generator." http://www.kombuchapower.com/colloidal_silver.htm Retrieved Feb 17, 2008.

Lantagne, D. (2001). Investigation of the Potters for Peace Colloidal Silver Impregnated Ceramic Filter. Report 1: Intrinsic Effectiveness. Jubilee House Community. December 2001.

Mintz, E., J. Bartram, et al. (2001). "Not just a drop in the bucket: Expanding access to pointof-use water treatment systems." American Journal of Public Health 91(10): 15651570.

Reed, B. J. and S. Coates (2003). "Engineering and gender issues - evidence from lowincome countries." Proceedings of the Institution of Civil Engineers-Municipal Engineer 156(2): 127-133. 
Rural-Poverty-Portal (2010). "Rural poverty in Uganda." Retrieved December 7, 2010.

Sobey, M. (2005). " Managing Water in the Home: Accelerated Heath." Retrieved December 7, 2010.

Tiwari S., S. W., Darby J., Kariuki Z. and Jenkins M ( 2009). "Intermittent slow sand filtration for preventing diarrhoea among children in Kenyan households using unimproved water sources: randomized controlled trial." Tropical Medicine \& International Health 14(11): 1374-1382.

Ujang, Z. and C. Buckley (2002). "Water and wastewater in developing countries: present reality and strategy for the future." Water Science and Technology 46(9): 1-9.

UNICEF (2010). "Uganda." Retrieved Accessed December 7, 2010

WHAI. (2008). "Silverdyne." World Health Alliance International Retrieved April, 2008.

World-Bank-Group (2009). "Uganda at a glance." Retrieved December 7, 2010.

World-Health-Organization ( 2010). "Water, Sanitation and Hygiene Links to Health Facts and Figures." Retrieved December 7, 2010.

Wright, J., S. Gundry, et al. (2004). "Household drinking water in developing countries: a systematic review of microbiological contamination between source and point-ofuse." Tropical Medicine \& International Health 9(1): 106-117. 